\title{
Bancos de sangre de cordón umbilical
}

\author{
MARCIAL OSORIO F. ${ }^{1}$ \\ 1. Jefe Neonatología Clínica Alemana Santiago. \\ Centro de Bioética. Facultad de Medicina. \\ Clínica Alemana Santiago Universidad del Desarrollo.
}

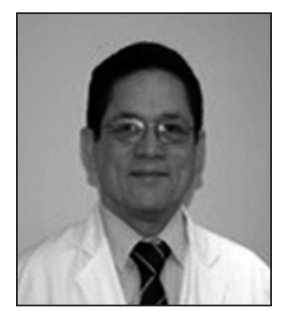

Los grandes descubrimientos y avances de la medicina en los últimos 50-60 años han permitido el desarrollo de nuevos tratamientos, y con ello un aumento de la calidad y expectativa de vida de vida. Entre estos descubrimientos el uso de células precursoras hematopoyéticas para el tratamiento de enfermedades malignas (leucemias y linfomas) y no malignas (Anemia Aplásica y Anemia de Fanconi), se ha vuelto una práctica relativamente común. Por otra parte, el uso potencial como alternativa terapéutica en diversas enfermedades (piel, aparato cardiovascular, endocrinología, neurología, sistema osteoarticular, etc.) ha impulsado una activa investigación que ha generado expectativas desproporcionadas, publicitadas a través de la literatura médica y de la prensa a la población general. Ante este panorama es importante enfatizar que la validez científica y utilidad potencial de las células precursoras hematopoyéticas aún no han sido establecidas, y su uso sigue siendo experimental.

Se llama célula madre o célula troncal a un tipo especial de célula indiferenciada que posee la capacidad de dividirse indefinidamente sin perder sus propiedades, y dar origen a células especializadas.

Desde el descubrimiento de la existencia de células madre en la sangre del cordón umbilical en 1974, y de estudios posteriores que demostraron que la proporción de células pro- genitoras hemopoyéticas en sangre de cordón es similar a la de la médula ósea adulta, ésta se ha transformado en una fuente de células madre hemopoyéticas pluripotenciales para ser utilizadas en trasplantes autólogos (obtenidas del propio paciente), o alogénicos (de un donante inmunológicamente compatible). $\mathrm{Su}$ fácil disponibilidad, con ausencia de riesgo o molestias para el donante, escaso riesgo de infección, y una menor tasa de rechazo respecto a células obtenidas de un donante adulto las ha convertido en una muy buena alternativa frente al trasplante de células de médula ósea. $\mathrm{La}$ posibilidad de manipularlas in vitro, logrando diferenciación a otras líneas celulares, abre un gran camino en la llamada medicina regenerativa y de reparación de tejidos dañados.

Si bien la recuperación de células es limitada por el volumen de sangre que se consigue en una muestra de cordón, ello se puede superar juntando sangre obtenida de dos o más cordones, y por la expansión in vitro de las mismas células, o la inducción de células madre pluripotentes.

Surge así la posibilidad de los Bancos de Sangre de Cordón, dada su utilidad clínica. El primer Banco se funda en Nueva York en 1992, con un crecimiento exponencial y el nacimiento de NETCORD, organización internacional cuyo objetivo es garantizar la calidad de los productos trasplantables, facilitar la interac-

Recibido el 18 de noviembre de 2013.

Correspondencia a:

Marcial Osorio F.

E-mail:marcialosorio@gmail.com 
ción con los centros de trasplante y/o registros, facilitar el análisis de los resultados clínicos y promocionar la investigación sobre este producto hematopoyético. Se crean dos modelos de bancos: los Bancos Públicos, por donación para trasplante alogénico, y los Bancos Privados, con fines de lucro, que pretenden ser un depósito para utilización autóloga para quién provee las células o para familiares cercanos, generalmente hermanos.

La conservación en Bancos Públicos se basa en los principios de altruismo (a quien lo pueda necesitar, en cualquier parte del mundo), confidencialidad y calidad, estrictos criterios de selección y un aprovechamiento reducido de las muestras, dado que se utiliza 1 de cada 4-5 muestras tomadas, lo cual se compensa dado el gran número de donantes. Este tipo de banco utiliza recursos públicos o provenientes de donaciones.

La conservación en Bancos Privados, para utilización propia, corresponde a un modelo comercial, carente o con mínimos criterios de selección y/o calidad. Se almacenan todas las muestras, se promete aplicaciones quizá irrealizables ,ya que no hay experiencia de conservación más allá de 20-25 años. Frecuentemente utilizan estrategias de marketing agresivas y poco transparentes dirigidas a un público en una fase particularmente vulnerable de su vida. Se entrega información sesgada, como por ejemplo el no mencionar que los trasplantes autólogos no son útiles en las enfermedades hereditarias, incluso tampoco en ciertas neoplasias, ya que la sangre del cordón umbilical puede contener alteraciones tumorales clónicas.

Las células depositadas en los Bancos Privados tienen un alto costo para los depositantes y una probabilidad tan baja como 1/20.000 a $1 / 250.000 d e$ ser requeridas algún día para trasplante autólogo. Algún autor ejemplifica esto diciendo que la posibilidad de uso se asemeja a la posibilidad de una persona normal de morir en un accidente aéreo comercial.

La justificación ética para los dos tipos de Bancos ha sido muy diferente y por eso los Bancos Privados han sido prohibidos en algunos países como Francia e Italia; otros países han exigido garantizar la existencia de al me- nos un Banco Público, en cumplimiento del principio de justicia social, antes de que se pueda crear un Banco Privado.

En Argentina y España, las muestras guardadas en un Banco Privado ingresan por ley a un registro nacional, y deben estar disponibles si son requeridas para trasplante alogénico. Este sistema permite la conservación de muestras "propias" en un Banco Público, para que puedan ser utilizadas por el donante o sus familiares próximos por indicación médica. Desde el punto de vista ético, en este tipo de modelo se preserva el derecho de propiedad y de los padres a la conservación de células madre para un posible uso autólogo, o de su familia, sin desatender un posible uso alogénico requerido por la comunidad.

En Chile, no existe legislación al respecto y el Banco Público existente es mantenido por filantropía de uno de los Bancos Privados.

A pesar del enorme crecimiento de los bancos de cordón, tanto a nivel público como privado, y de la creación de asociaciones internacionales de bancos públicos, aún no se consigue encontrar todos los donantes compatibles necesarios, lo cual plantea cuestionamientos de igualdad y oportunidad de acceso a la salud como parte de los derechos fundamentales, con especial atención a las poblaciones minoritarias y haplogrupos menos frecuentes.

Parece fundamental sensibilizar a las autoridades políticas para legislar a favor de los usuarios y enfermos trabajando en la creación de un Banco Público. El alto costo de operación de estos bancos plantea la necesidad de coordinar esfuerzos no solo a nivel nacional, sino latinoamericano, de modo de aumentar el número de muestras conservadas en poblaciones de orígenes similares a una masa crítica y con ello, la posibilidad de conseguir donantes compatibles.

Del mismo modo se debe fomentar la educación de nuestra ciudadanía con la entrega y difusión de información realista, de acuerdo a los conocimientos científicos disponibles. Que sepan cuáles son las verdaderas indicaciones y las posibles terapias futuras que se puedan originar del material de origen fetal y sus células derivadas, enfatizando su estado actual, aún de carácter experimental, y por tanto, incierto. 
Corresponde a una ética de mínimos exigir acreditación de los Bancos Privados, con igualdad de criterios de calidad para todas las muestras almacenadas en el país. Nuestros bancos deben cumplir los estándares de calidad científico-técnica establecidos a nivel internacional para poder formar parte de redes que superen nuestras fronteras, aumentando la posibilidad de obtener donantes compatibles. Una adecuada educación de nuestros profesionales y de la población llevará a entender la escasa utilidad de la criopreservación exclusivamente para trasplante autólogo (banco privado), y de las ventajas de contar con un adecuado número de muestras disponibles para trasplante alogénico en un Banco Público. Una vez creado un Banco Público con recursos adecuados, se debiera enfatizar la importancia de la donación solidaria consentida de sangre de cordón, en el momento del parto, para uso en trasplantes alogénicos.

La publicidad de servicios comerciales en maternidades, servicios de obstetricia, centros de salud y vía pública, debe ser monitorizada por instancias como el SERNAC, cautelando que las aplicaciones terapéuticas publicitadas tengan validez y utilidad clínica comprobadas. Dadas las características del material biológico tal vez lo más correcto sea que no se acepte publicidad comercial, sino solo educativa, orientada a fomentar la donación como sucede con la donación para trasplantes o bancos de sangre.

Dados los argumentos expuestos, el personal de salud debe estar atento y actualizado para no caer por desconocimiento en la oferta de comisiones o compensaciones directas o indirectas ofrecidas para que incentiven la conservación en bancos privados, realizada por los inversionistas en estos bancos.

En resumen, dado el estado actual de conocimientos, parece aconsejable legislar y fomentar un Banco Público Estatal de cordón que tenga vinculación con alguna red internacional de bancos de cordón. La presencia de bancos privados debiera ser respetada en aras de la libertad de elección, pero es necesario que se sometan a regulaciones técnicas apropiadas. Toda información debe respetar veracidad y estándares éticos evitando toda forma de lucro con la esperanza como ocurre con frases como ..."un seguro de vida para su hijo" y similares. 